\title{
Effect of boric acid on sodium fluoride toxicity in chicks
}

\author{
E.H. Alabbasi ${ }^{1}\left(\mathbb{D}\right.$ and Y.Z. Al-Abdaly ${ }^{2}(\mathbb{D}$ \\ ${ }^{1}$ Nineveh Agriculture Directorate, ${ }^{2}$ Department of Physiology, Biochemistry and Pharmacology, Collage of Veterinary \\ Medicine, University of Mosul, Mosul, Iraq
}

\begin{tabular}{l} 
Article information \\
\hline Article history: \\
Received February 05, 2021 \\
Accepted March 21, 2021 \\
Available online November 20, 2021 \\
\hline Keywords: \\
Sodium fluoride \\
Boric Acid \\
Toxicity \\
Chicks \\
\\
\hline Correspondence: \\
E.H. Alabbasi \\
enaamhabeeb2019@ gmail.com
\end{tabular}

\begin{abstract}
The aim of this study to explore the therapeutic effect of boric acid on the neurobehavioral (motor activity) level, and histopathologic changes in the brain, liver and kidneys against fluorosis. In this study rose chicks have been used and determined medium lethal sodium fluoride dose at $346.5 \mathrm{mg} / \mathrm{kg}$ orally. The chicks divided into four random groups each one consists of 10 chicks. The first group considered to be a control group, the second received $20 \mathrm{mg} / \mathrm{kg}$ of sodium fluoride, the third group received $10 \mathrm{mg} / \mathrm{kg}$ of boric acid and the fourth received $20 \mathrm{mg} / \mathrm{kg}$ of sodium fluoride and boric acid at the same previous dosages. After two weeks of daily treatment, neurobehavioral measures were taken, the use of boric acid has a major effect to improve the neurobehavioral measurement and develop complications of ALT, AST, creatinine, $\mathrm{Ca}$, MDA. The results indicate that boric acid may be a therapeutic agent against the fluoride toxicity of the brain, liver and kidney. This result support by histopathological changes which represented by inflammation, congestion of portal vein and dilation of sinusoids in the liver and vacuolation, vasogenic edema and gliosis in the brain and Kidney of showed segmentation of glomeruli, dilation of Bowman's space, necrosis of epithelial cells renal tubules and hemorrhage of $\mathrm{NaF}$ group, while the liver of the $\mathrm{NaF}$ with boric acid group showed an improvement the results of histopathological examination of the liver, brain and kidneys compared to the $\mathrm{NaF}$ group alone. The results revealed that boric acid has a preventing effects against fluoride after two weeks of treatment with boric acid.
\end{abstract}

DOI: 10.33899/ijvs.2021.129497.1653, (A)Authors, 2022, College of Veterinary Medicine, University of Mosul.

This is an open access article under the CC BY 4.0 license (http://creativecommons.org/licenses/by/4.0/).

\section{Introduction}

Fluoride is an essential substance in the production of fluoridated dental preparations and in the drinking water (1). Drinking water, fruit, dental products, pesticides and rodenticides are the major sources of fluoride toxicity. Excessive exposure to fluorides, especially in the tooth and skeleton, leads to many health problems (2). Fluorine's electronegativity means that it is negatively charged and appears to pass through ion channels via cell membranes (3). Excessive ingestion of fluorine contributes to toxicity, which poses a major health threat with skeleton and dental defects. The major cause of fluorosis is contamination of organic and inorganic waste by drinking water (4). Since fluorine is ionic in drinking water, it is rapidly absorbed through the intestinal epithelia and, after accumulation in various organs, interferes with metabolic processes (3). Studies in rats have shown that fluoride in drinking water can damage and build soft tissue (5). In addition, it reduces the amount of antioxidant enzymes, such as catalase (CAT) and superoxide dismutase (SOD) and peroxidase glutathione, by generating fluorine-inducing free radicals. Furthermore, increased lipid peroxidation is a major oxidative stress biomarker. Studies in rats find that exposure to fluoride in rat tissue improves lipid peroxidation as ROS production (6).

Fluoride exposure was also shown to cause chromosome defects and damage to the DNA with 
genotoxic effects (7). The median lethal dose is $2,95 \mathrm{~g} / \mathrm{kg}$ of boric acid in chick $(8,9)$. Boric acid is an ingredient present as a trace element in animal bodies. It's a typical boron shape. It is water soluble and can be used in biochemical processes (10). Monobasic molecules of boric acid contain hydroxyl structures and release protons in a reaction (3). The integrity of the cell membranes and redox metabolism can play a significant role, even with a high association of boric acid to certain important molecules that are associated with biochemical and physiological processes, such as dinucleotide nicotinamide adenine, dinucleotide (11).

Boric acid is used in many fields of industry and agriculture. It moves through the digestive system easily when swallowed into the bloodstream (4). Latest findings indicate that the boric acid can be used to treat some types of cancer in animals (12). In previous studies, boric acid was identified as having protective effects from inflammatory and oxidative damage in rat, in hormone metabolism, membrane signaling and different processes of enzymes, Boric acid function as an antioxidant (13).

The aim of this study was to investigate therapeutic impacts of boric acid on neurobehavioral and motor toxicity and the histopathological impacts of brain, liver and kidney and to correlate all of this with enzyme- and mineral-level changes in chicken's bodies due to an increase in the prevalence of fluorosis clinics. The neuro-motor behavior of the chicks, liver enzyme and creatinine functions, phosphors and calcium, and MDA and their relationship with evident pathologic changes in the brain, liver and kidney were examined in order to confirm our hypothesis.

\section{Materials and methods}

\section{Animals}

In this study the chicks were species of rose meat, brought from one day and grew up in animal house halls of the College of Veterinary Medicine. The experiment started at age 7 days and has been supplied with concentrated feed provided by a local company in order to provide fodder.

\section{Chemicals}

Sodium fluoride in powder from BDH limited pool England was used in this study and boric acid in powder form Scharlou company Spain, dilute formalin was used for sample preservation, Kits for measuring enzymes and minerals from Biolabo, Biomerieux, France company.

\section{Experimental design}

The median lethal dose of $\mathrm{NaF}$ in chickens was calculated according to the Dixon method by up and down method (14). The chicks were divided into 4 main groups each one consists of 10 chicks. The first group was considered a control group was not given anything. the second group received a dose of $20 \mathrm{mg} / \mathrm{kg}$ body weight of sodium fluoride and the third group received a dose of 10 $\mathrm{mg} / \mathrm{kg}$ body weight of boric acid, while the fourth group received a dose of $20 \mathrm{mg} / \mathrm{kg}$ sodium fluoride and boric acid at $10 \mathrm{mg} / \mathrm{kg}$. The treatment was for a while for 5 days/week for 2 weeks of treatment. The volume of admiration was 5$10 \mathrm{ml} / \mathrm{kg}$.

Neurobehavioral and tonic immobility response tests were taken. Then the blood was collected from the animals by cutting their jugular veins to extract the serum for biochemical studies. The animals slaughtered in order to collect organs and store them in formalin before histopathology was performed and the pathological changes were study.

\section{Median lethal dose LDso} (14)

Calculated according to Dixon up and down method

\section{Open felid motor activity test}

A purpose-built wooden box measuring $90 \times 60 \times 30$ $\mathrm{cm}$, with a divided floor into 24 equal squares and a square side length of $15 \mathrm{~cm}$, was used for this test. Each chick is subjected to the test alone. The counting of the number of squares for the chick crosses for 3 minutes. After 2 weeks of treatment at the end of this test, animals were subjected to the tonic immobility response test (15).

\section{Tonic immobility response test}

This test is conducted by calmly putting each chick on the side of the body, then placing the right hand palm on the animal for 15 seconds to calm down, then quietly pulling the hand and measuring the time of the chick still without moving (the time of inactivity) before the chick starts to resist and move, an animal that fails to calm down is tried again for 5 attempts with an interval between attempts. The overall rest is 300 seconds (16).

\section{Malondialdehyde measurement}

Malondialdehyde was measured according to the Buege and Aust method (17).

\section{Histopathic examination}

Necropsy was performed at the end of the experiment to study microscopic pathological changes in the Brain, kidneys and liver. The organs were quickly removed and washed with tap water.

They transferred to special containers to store the samples in a $10 \%$ neutral buffered formalin solution for three days, then washed in tap water Later, the specimen crossed in alcohol, xylene, enameled in the form of patterns, microtome slides of up to 5 microns with a thickness of 4-5 $\mu \mathrm{m}$ were cut off from each block and then stained with hematoxylin and eosin.

Light microscope was used for study, and the affected areas were photographed (18). 


\section{Statistical analysis}

The ANOVA test was used to analyze parametric data (one way), the spss software was used, then the results were subjected to the LSD test. As for the non-parametric data, the PAST program was used to submit it to the Mann Whitney test.

\section{Results}

The median lethal dose of fluoride in chicks was 346.5 $\mathrm{mg} / \mathrm{kg}$ (Table 1). The results after 2 weeks of acute fluoride treatment indicated a significant decreased in the number of squares crossed by chicks in the group treated with fluoride alone in open field test, as well as an increase in the calm time in the tonic immobility response test compared to the control group and other groups (Table 2). A significant increase in enzymes AST, CREATININ, ALT and decrease in $\mathrm{Ca}$ in the group treated with fluoride alone was found in the results of the biochemical tests compared to the control and other groups, a significant increase in the ALT level was observed when the fluoride-treated group was compared with the rest of the groups (Table 3).

In the group treated with fluoride and boric acid, calcium recorded a significant difference compared to the group treated with fluoride alone. These findings indicate that the group treated with fluoride and boric acid improved compared to the group treated with fluoride alone. MDA showed a significant increase in the sodium fluoride-only treatment group compared to the rest of the groups (Table 3).

The histological changes in the liver, brain and kidneys showed the presence of differentiated histopathological changes after two weeks, which represented by congestion of sinusoids and portal vein in liver of chicks in boric acid group (Figure 1).

Photomicrograph of chick's brain of boric acid group shows normal architecture of brain tissue representing by neurons, glial cells, and blood vessels (Figure 2).

Photomicrograph of chick's kidney of boric acid group shows normal architecture of renal tissue representing by glomeruli, proximal renal (Figure 3).

Table 1: The median lethal dose of sodium fluoride in chicks

\begin{tabular}{ll}
\hline Variables & Result \\
\hline LD50 & $346.5 \mathrm{mg} / \mathrm{kg}$, orally \\
The range of the doses & $400-325 \mathrm{mg} / \mathrm{kg}$, orally \\
Initial dose & $400 \mathrm{mg} / \mathrm{kg}$, orally \\
Last Dose & $325 \mathrm{mg} / \mathrm{kg}$, orally \\
Number of chicks & $6(\mathrm{XX0XX0)*}$ \\
Increase or decrease in dose & $25 \mathrm{mg} / \mathrm{kg}$, orally \\
Signs of toxicity & Fatigue, feather erections, \\
& lack of movement and \\
& paralyses other signs \\
\hline$*$ X means death and O refer to the survival of chicks.
\end{tabular}

Table 2: Tonic immobility response and Motor activity (Number of squares) after 2 weeks of treatment with sodium fluoride and boric acid alone, or both of them in chicks

\begin{tabular}{|c|c|c|}
\hline Groups and doses & Tonic immobility response time & Motor activity \\
\hline Control & $60.30 \pm 18$ & $5 \pm 1$ \\
\hline Sodium Fluoride $20 \mathrm{mg} / \mathrm{kg}$ & $* 300 \pm 60$ & $* 2 \pm 1$ \\
\hline Boric Acid $10 \mathrm{mg} / \mathrm{kg}$ & a $70.44 \pm 27$ & ${ }^{\mathrm{a}} 4 \pm 1$ \\
\hline $\begin{array}{l}\text { Sodium Fluoride } 20 \mathrm{mg} / \mathrm{kg} \\
\text { and Boric Acid } 10 \mathrm{mg} / \mathrm{kg}\end{array}$ & a $75 \pm 14$ & a $4 \pm 1$ \\
\hline
\end{tabular}

Table 3: Concentration of enzymes in the serum after 2 weeks of Treatment with sodium fluoride and boric acid alone or together in chicks

\begin{tabular}{|c|c|c|c|c|c|c|}
\hline Treatment and doses & $\begin{array}{c}\text { ALT } \\
\text { (Unit/l) }\end{array}$ & $\begin{array}{c}\text { AST } \\
\text { (Unit/l) }\end{array}$ & $\begin{array}{c}\text { Crea } \\
(\mathrm{mg} / 100 \mathrm{ml})\end{array}$ & $\begin{array}{c}\mathrm{P} \\
(\mathrm{mg} / 100 \mathrm{ml}) \\
\end{array}$ & $\begin{array}{c}\mathrm{Ca} \\
(\mathrm{mg} / 100 \mathrm{ml})\end{array}$ & $\begin{array}{c}\text { MDA } \\
\text { (Nanomol/L) }\end{array}$ \\
\hline Control & $11 \pm 0.4$ & $152 \pm 32$ & $0.07 \pm 0.01$ & $6.95 \pm 3$ & $10.9 \pm 3$ & $11 \pm 3$ \\
\hline Sodium Fluoride $20 \mathrm{mg} / \mathrm{kg}$ & $13 \pm 2 *$ & $164 \pm 13 *$ & $0.1 \pm 0.03 * \mathrm{cb}$ & $6.57 \pm 2$ & $8.92 \pm 2 * b c$ & $13.5 \pm 2 * \mathrm{bc}$ \\
\hline $\begin{array}{l}\text { Sodium Fluoride } 20 \mathrm{mg} / \mathrm{kg} \\
\text { and Boric Acid } 10 \mathrm{mg} / \mathrm{kg}\end{array}$ & $11.5 \pm 2^{a b}$ & $149 \pm 22^{a b}$ & $0.07 \pm 0.01^{\mathrm{a}}$ & $7 \pm 1$ & $9.3 \pm 2$ & $12 \pm 2$ \\
\hline
\end{tabular}

Each group consists of 6 animals. Data represent as mean \pm SE. *significant difference from the control group, $\mathrm{P}<0.05$. a represented a significant difference from the group of sodium fluoride. b significant difference from the group of boric acid. $c$ significant difference from sodium fluoride and boric acid group. 


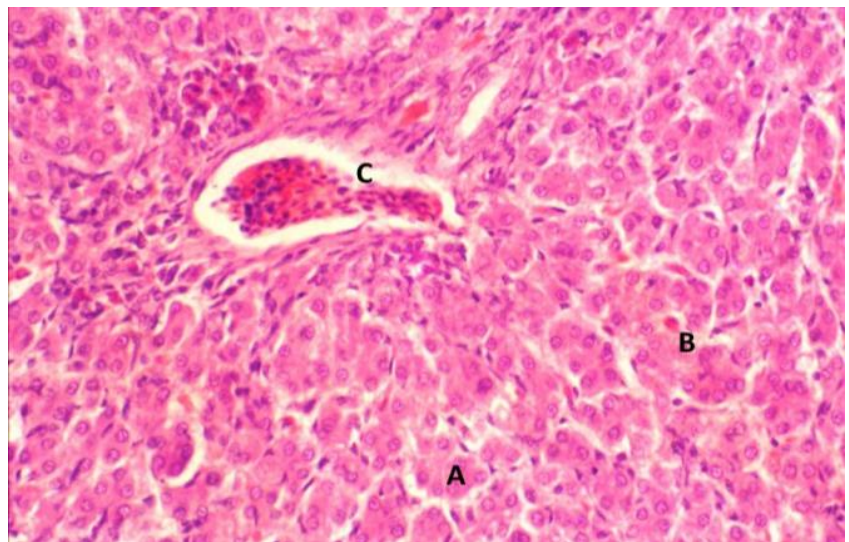

Figure 1: photomicrograph of chicken liver of boric acid group (for 2 weeks) shows normal architecture of hepatic tissue representing by hepatocytes (A), congestion of sinusoids (B) and portal vein (C). H\&E stain, 400X.

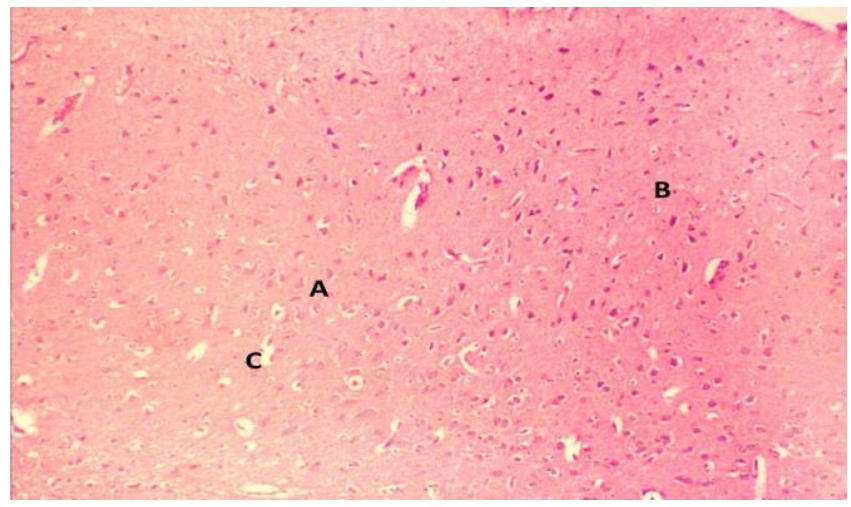

Figure 2: photomicrograph of chicken brain of boric acid group (for 2 weeks) shows normal architecture of brain tissue representing by neurons (A), glial cells (B), and blood vessels (C). H\&E stain, 100X.

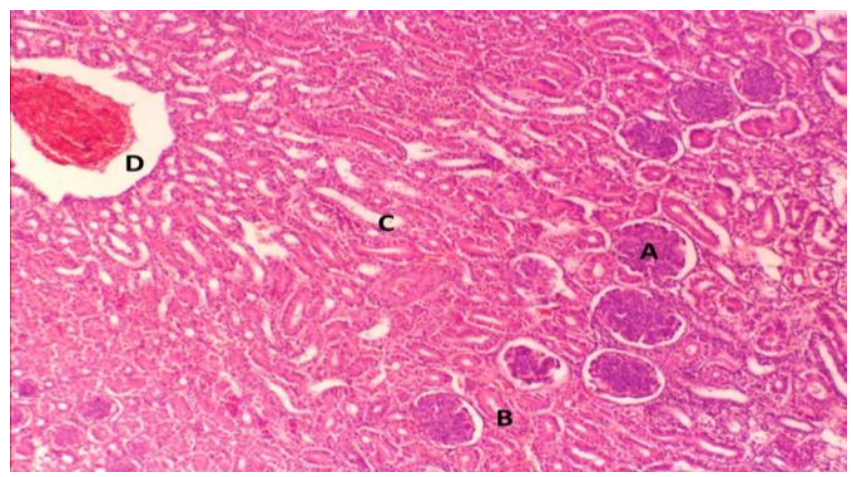

Figure 3: photomicrograph of chicken kidney of boric acid group (for 2 weeks) shows normal architecture of renal tissue representing by glomeruli (A), proximal renal tubules (B), distal renal tubules (C) and congestion of renal vein (D). H\&E stain, 100X.
While in $\mathrm{NaF}$ group showd focal infiltration of inflammatory cells, congestion of portal vein and dilation of sinusoids (Figure 4-6). In the brain of $\mathrm{NaF}$ group shows vacuolation, vasogenic edema, gliosis and congestion of blood vessels (Figure 7 and 8) more than lesion (Figure 9) shows recent thrombus (erythrocytes, platelets and fibrin).

Kidney of $\mathrm{NaF}$ group shows segmentation of glomeruli, dilation of Bowman's space, necrosis of epithelial cells lining renal tubules and hemorrhage (Figure 10).

Atrophy of glomeruli, cell swelling and necrosis of epithelial cells lining renal tubules, focal infiltration of inflammatory cells and congestion of renal vein (Figure 11 and 12), while in the groups of mixture of $\mathrm{NaF}$ and boric acid shows mild cell swelling of hepatocytes, congestion of central vein and portal vein (Figure 13 and 14).

In the $\mathrm{NaF}$ with boric acid group shows normal architecture of brain tissue except vasogenic edema (Figure 15). Kidney of $\mathrm{NaF}$ with boric acid group appears mild vacuolar degeneration of epithelial cells lining renal tubules, congestion of blood vessels, sinusoids (Figure 16).

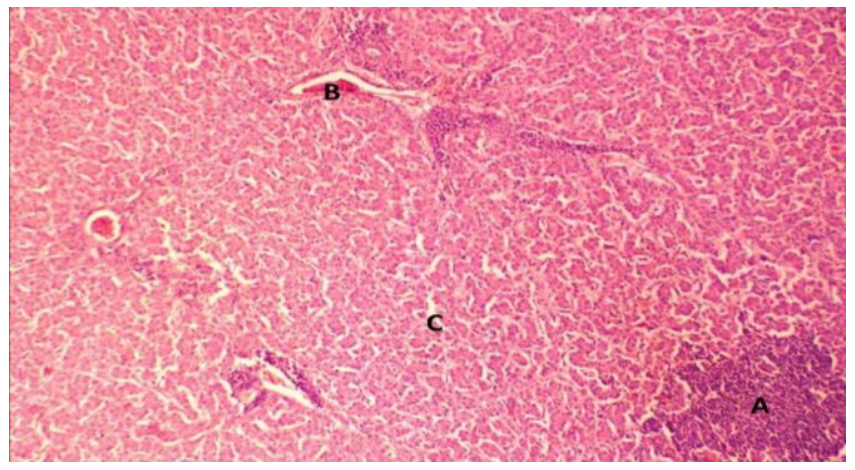

Figure 4: photomicrograph of chicken liver of $\mathrm{NaF}$ group (for 2 weeks) shows focal infiltration of inflammatory cells (A), congestion of portal vein (B) and dilation of sinusoids (C). H\&E stain, 100X.

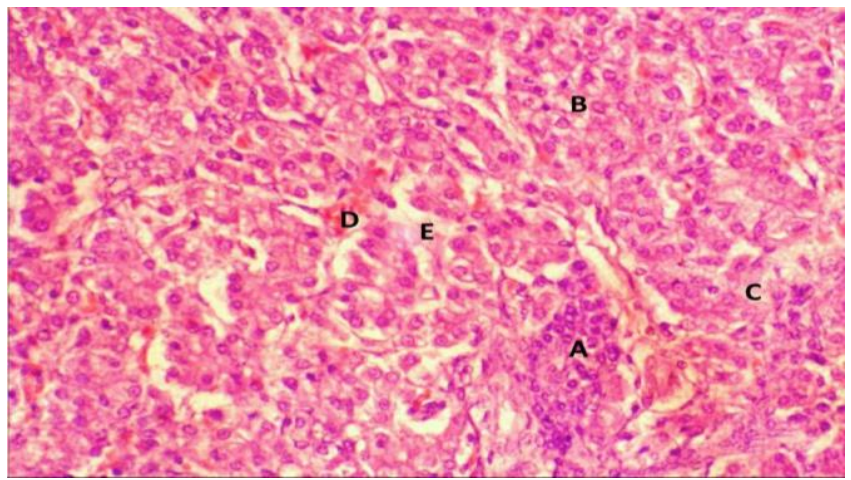

Figure 5: photomicrograph of chicken liver of $\mathrm{NaF}$ group shows focal infiltration of inflammatory cells (A), vacuolar degeneration (B) necrosis of hepatocytes (C), congestion of sinusoids (D) dilation of sinusoids (E). H\&E stain, 400X. 


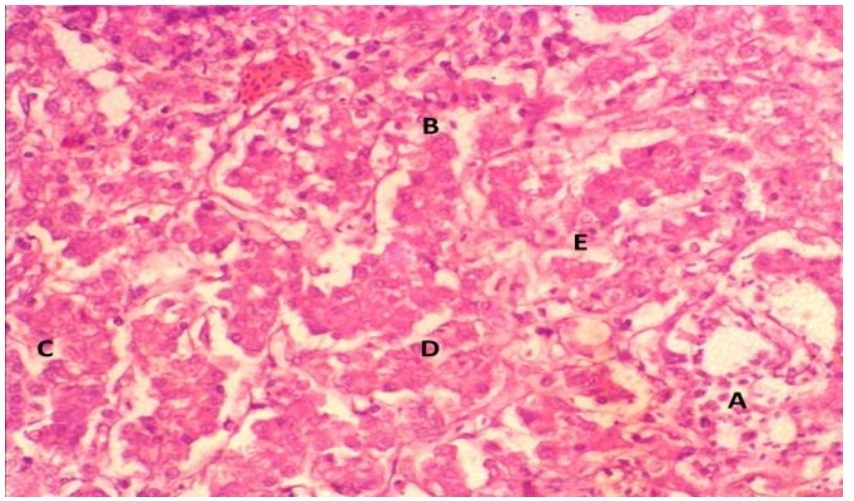

Figure 6: photomicrograph of chicken liver of $\mathrm{NaF}$ group shows infiltration of inflammatory cells (A), vacuolar degeneration (B) and necrosis of hepatocytes (C), congestion of sinusoids (D) and dilation of sinusoids (E). H\&E stain, $400 \mathrm{X}$.

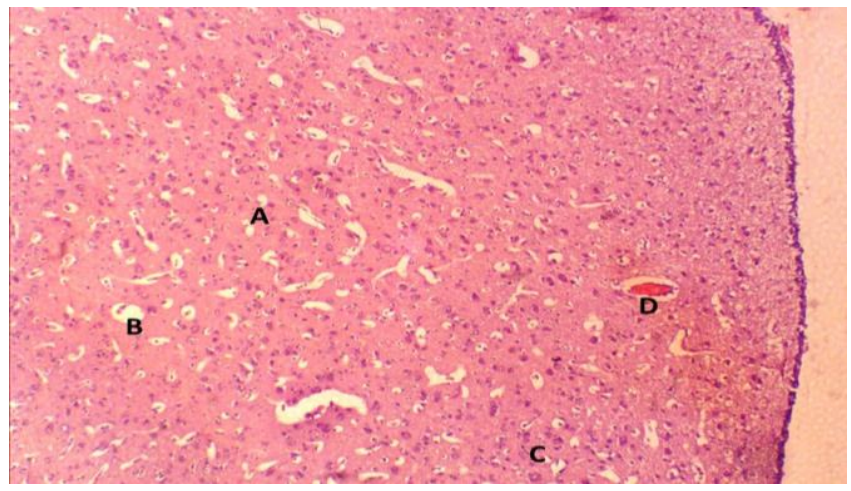

Figure 7: photomicrograph of chicken brain of $\mathrm{NaF}$ group (for 2 weeks) shows vacuolation (A), vasogenic edema (B), gliosis (C) and congestion of blood vessels (D). H\&E stain, $100 \mathrm{X}$.

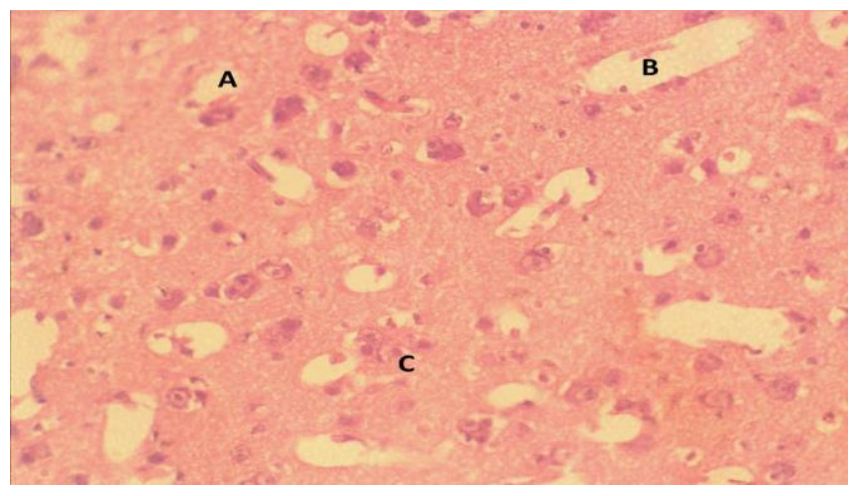

Figure 8: photomicrograph of chicken brain of $\mathrm{NaF}$ group (for 2 weeks) shows presence of vacuolation in cytoplasm of neurons (A), vasogenic edema (B) and gliosis (C). H\&E stain, $400 \mathrm{X}$.

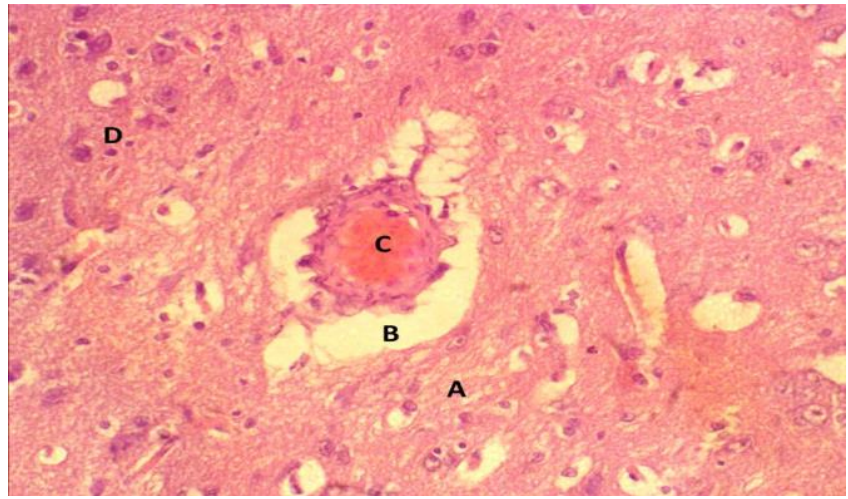

Figure 9: photomicrograph of chicken brain of $\mathrm{NaF}$ group (for 2 weeks) shows presence of vacuolation in cytoplasm of neurons (A), vasogenic edema (B), recent thrombus (erythrocytes, platelets and fibrin) (C) and gliosis (D). H\&E stain, 400X.

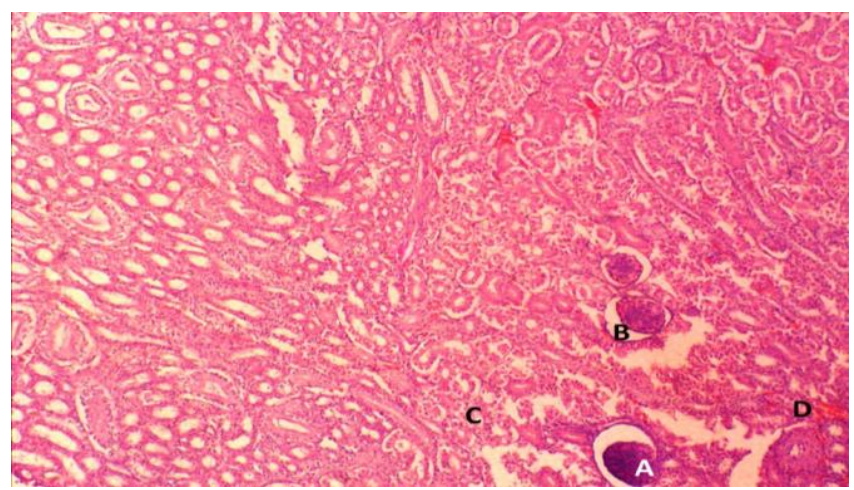

Figure 10: photomicrograph of chicken kidney of $\mathrm{NaF}$ group shows segmentation of glomeruli (A), dilation of Bowman's space (B) necrosis of epithelial cells lining renal tubules (C) and hemorrhage (D). H\&E stain, 100X.

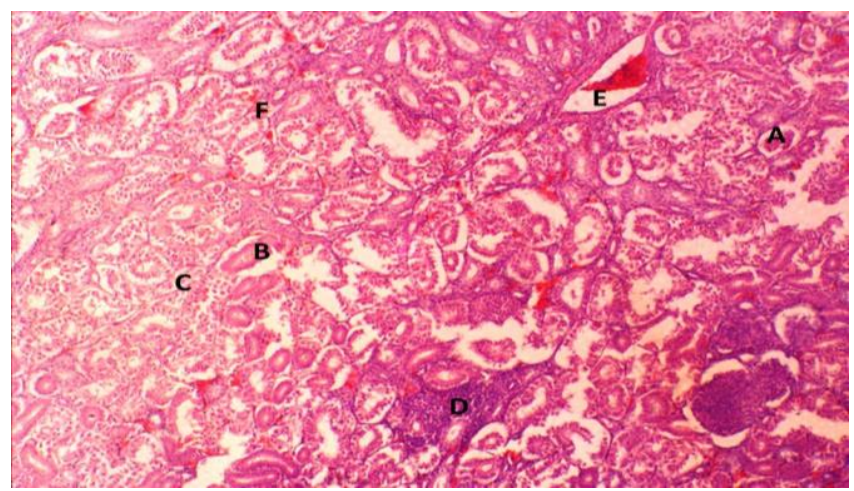

Figure 11: photomicrograph of kidney of $\mathrm{NaF}$ group shows atrophy of glomeruli (A), cell swelling (B) necrosis of epithelial cells (C), focal infiltration of inflammatory cells (D) congestion (E) hemorrhage (F). H\&E stain, 100X. 


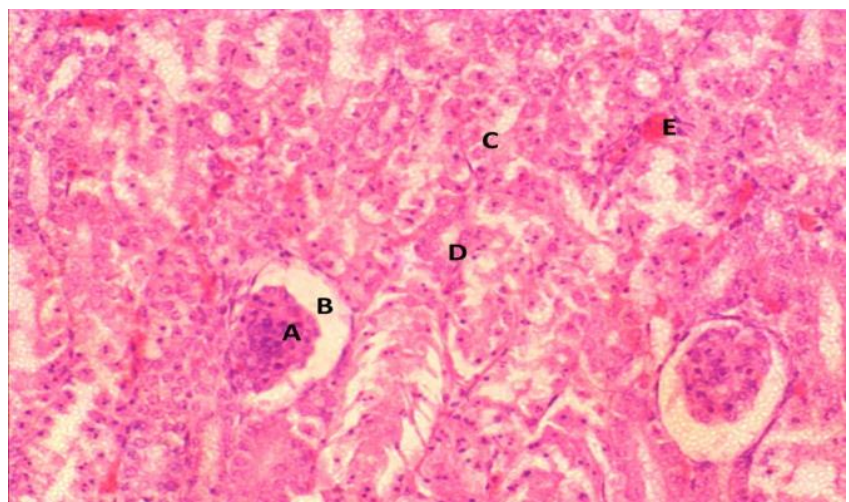

Figure 12: photomicrograph of chicken kidney of $\mathrm{NaF}$ group shows atrophy of glomeruli (A), dilation of Bowman's space (B), cell swelling (C) and coagulative necrosis of epithelial cells lining renal tubules (D) and congestion of blood vessel (E). H\&E stain, 400X.

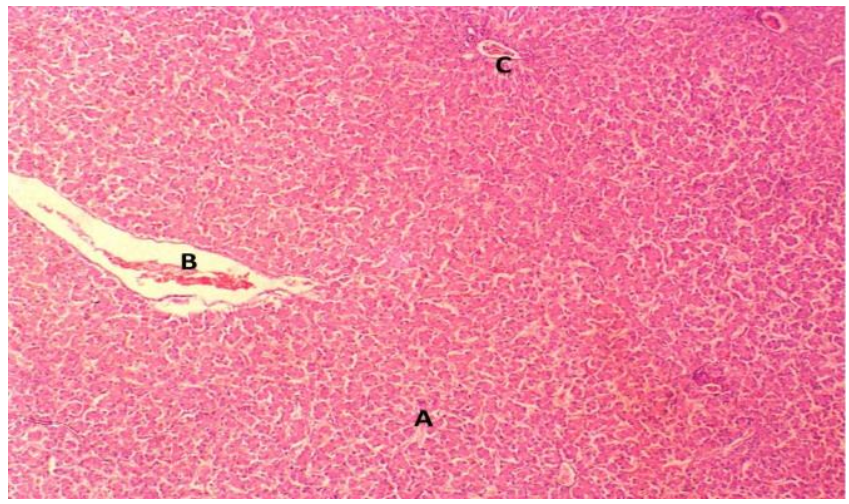

Figure 13: photomicrograph of chicken liver of $\mathrm{NaF}$ with boric acid group (for 2 weeks) shows mild cell swelling of hepatocytes (A), congestion of central vein (B) and portal vein $(\mathrm{C})$. H\&E stain, 100X.

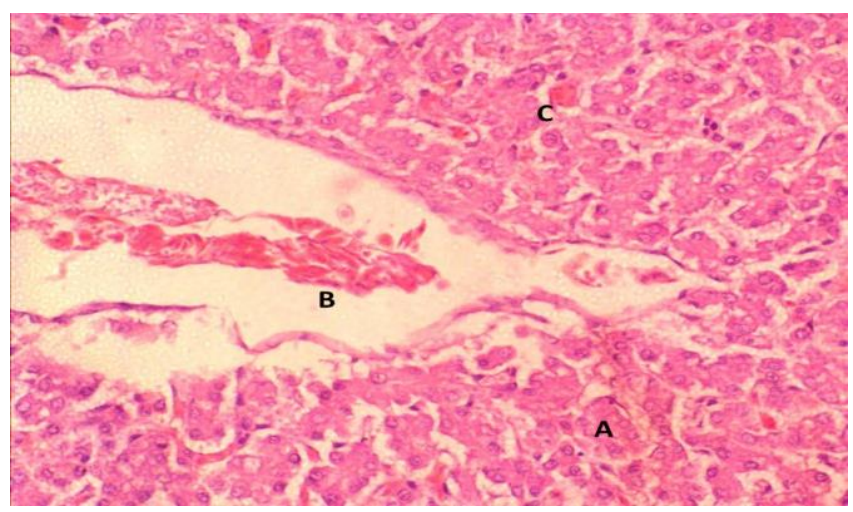

Figure 14: photomicrograph of chicken liver of $\mathrm{NaF}$ with boric acid group (for 2 weeks) shows mild cell swelling of hepatocytes (A), congestion of central vein (B) and sinusoids (C). H\&E stain, 100X.

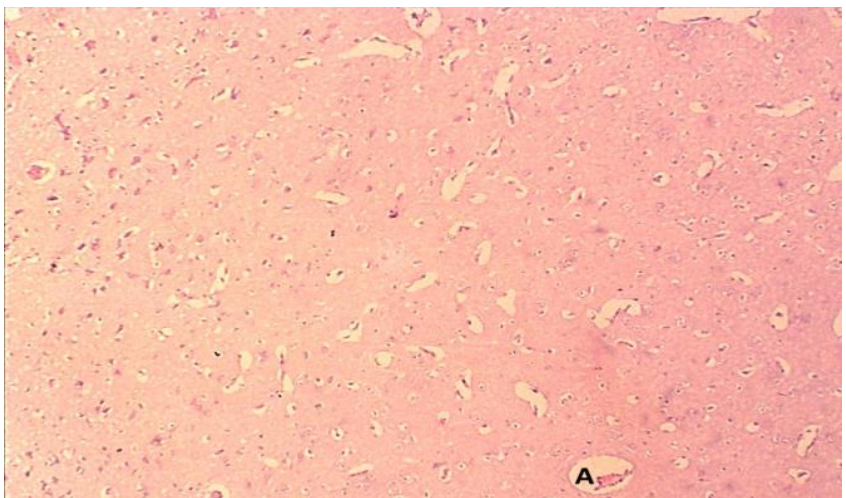

Figure 15: photomicrograph of chicken brain of $\mathrm{NaF}$ with boric acid group (for 2 weeks) shows presence the normal architecture of brain tissue and cells all over the section, with one exception is presence vasogenic edema (A). H\&E stain, 100X.

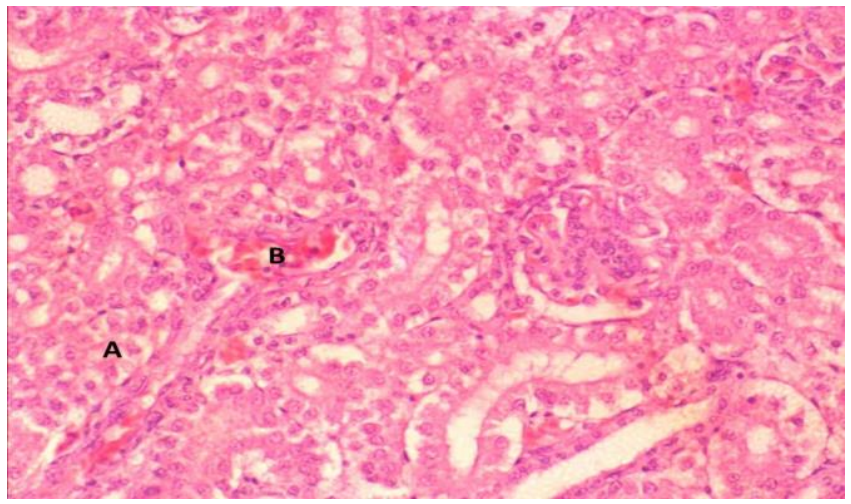

Figure 16: photomicrograph of chicken kidney of $\mathrm{NaF}$ with boric acid group shows mild vacuolar degeneration of epithelial cells lining renal tubules (A) congestion of blood vessels sinusoids (B). H\&E stain, 400X.

\section{Discussion}

The group treated with mixture of fluoride with boric acid showed an improvement in the animal clam time in the tonic immobility test relative to the animals treated with fluoride alone. Whereas prolonged duration of inactivity (clam) has been reported in chicks of sodium fluoride group this may be due to animal's feelings of fear and anxiety (opposite of claim), or to the effects on serotonin and other neurotransmitters (19).

Synapses that play a significant role in the transmission of nerve signals are strongly linked to neurotoxicity due to oxidative stress (20). Since fluorine has the property of crossing the blood-brain barrier (7), nerve cells are highly susceptible to fluoride damage and neuronal fat and protein oxidation due to their high mitochondrial content, especially the presynaptic nerve cell and this result 
confirms that boric acid in cells may be an antioxidant agent $(6,21)$.

As it was found that fluoride exposure in rabbit increased levels of MDA in synapses by raising oxidative stress (22), our findings are compatible with other research. In one study, treatment with boric acid was also found to affect synaptosomes in the brain of rat, as it led to a significant improvement in antioxidant enzyme levels (23).

For their effect on the elimination of free radicals. In other words, by helping the antioxidant defense mechanism, boric acid helps protect cells. In the group treated with fluoride alone the movement of animals was also greatly affected by inhibiting the movement and a decreased the number of squares crossed by the chick within the open field, and this may be due to inhibiting the activity of $\mathrm{Na} / \mathrm{K}$ ATPase in the brain tissue, which is reflected in the open field neurobehavioral and motor activity (24).

The sodium-potassium pump is a protein imbedded in the neural membrane that plays an important role in the maintenance of the cells' electrochemical membrane potential, it is also involved in the provision inside and outside the cells of electrolyte balances (25).

Fluoride binds to and prevents the function of ion channel proteins in cell membranes (26), which causes the membrane translucency to deteriorate and this explains was found in this research.

An improvement in the neuromotor activity of the animals was recorded in the groups treated with fluoride with boric acid, as well as a marked improvement in the level of the ALT and AST enzymes. This improvement may be attributable to the fact that boron interacts with fluoride and forms a fluoride-boron complex that is not absorbable, and this complex is excreted outside the body via the kidney (27).

That result was supported by histopathological changes in liver and kidney, where improvement was observed with the pathological changes in the liver and kidneys of the group treated with mixture of $\mathrm{NaF}$ with boric acid. In previous studies, fluoride in rats was the cause of oxidative stress, damage to DNA, activation of apoptotic pathways, and changes in the cell cycle $(6,13)$.

The development of cellular degeneration and the resulting degeneration due to tissue damage and necrosis in the liver or heart or possible which muscle damage due to the use of a drug or toxic chemical (28) is a possible mechanism for raising the concentration of ALT and AST enzymes in the serum. There are variations in enzyme levels that may be due to individual differences, as the reaction of birds to medications differs and varies depending on the stress to which the animal is subjected and the sensitivity of the animal. The liver is a primary foreign body detoxification site, and the toxic agent is readily altered by metabolism. Because of its capacity to remove and concentrate toxic substances from highly specialized cells, the kidney also is a special target organ for toxic foreign substances (29).

Therefore, one of the target organ for the toxicity of sodium fluoride that has been linked with high levels of creatinine, ALT and AST enzymes in fluoride-treated animals, as well as with the toxic reactions of certain organs that have appeared in the form of pathological changes in the liver and brain organs, whereas fluoride is primarily involved in the production of reactive oxygen and derivatives of nitrogen.

The results showed a decrease in serum calcium levels only in the fluoride group compared to the rest of the groups, and this corresponds to many studies that attributed to the fact that fluoride interferes with the metabolism of calcium $(30,31)$.

In the group treated with fluoride with boric acid, there is a substantial improvement in the level of liver function enzymes and creatinine, as boric acid acts to preserve the integrity of the cell membrane, maintain its function and minimize DNA damage because of its similar affinity with other metabolites in the cells of the body of the animal by acting on the balance of oxidation and reduction $(32,33)$.

\section{Conclusion}

Boric acid, by behavioral studies assisted via histopathological brain examination, has a preventive effect on fluoride toxicity at the level of open field motor activity and nervous behavior of chicks, and has also help to minimize fluoride toxicity in the liver and kidneys. Evaluating the function of the enzymes ALT, AST, creatinine, $\mathrm{Ca}$ and MDA with histopathological modifications in the liver and kidney sections has shown this.

\section{Acknowledgement}

The study was supported by College of Veterinary Medicine, University of Mosul.

\section{Conflict of interest}

There is no conflict of interest.

\section{Reference}

1. Kanduti D, Sterbenk P, Artnik B. Fluoride: A review of use and effects on health. Mat Socio Med. 2016;28(2):133. DOI: 10.5455/msm.2016.28.133-137

2. Ozsvath DL. Fluoride and environmental health: a review. Rev Environ Sci Biotechnol. 2009;8(1):59-79. DOI: 10.1007/s11157-0089136-9

3. Swallow S. Fluorine in medicinal chemistry. Prog Med Chem. 2015;54(1):65-133. DOI: 10.1016/bs.pmch.2014.11.001

4. Ghosh G, Mukhopadhyay DK. Human health hazards due to arsenic and fluoride contamination in drinking water and food chain. 
Groundwater Devel Manag. 2019:351-369. DOI: 10.1007/978-3-31975115-3_15

5. Ferreira MK, Aragao WA, Bittencourt LO, Puty B, Dionizio A, de Souza MP, Buzalaf MA, de Oliveira EH, Crespo-Lopez ME, Lima RR. Fluoride exposure during pregnancy and lactation triggers oxidative stress and molecular changes in hippocampus of offspring rats. Ecotoxicol Environ Safet. 2020;208:111437. DOI: 10.1016/j.ecoenv.2020.111437

6. Goschorska M, Gutowska I, Baranowska I, Piotrowska K, Metryka E, Safranow K, Chlubek D. Influence of acetylcholinesterase inhibitors used in Alzheimer's disease treatment on the activity of antioxidant enzymes and the concentration of glutathione in THP-1 macrophages under fluoride-induced oxidative stress. Inter J Environ Res Public Hlth. 2019;16(1):10. DOI: 10.3390/ijerph16010010

7. Volobaev VP, Serdyukova ES, Kalyuzhnaya EE, Schetnikova EA, Korotkova AD, Naik AA, Bach SN, Prosekov AY, Larionov AV. Investigation of the genotoxic effects of fluoride on a bone tissue model. Toxicol Res. 2020;24:1-6. DOI: 10.1007/s4318833-02000039-0

8. Sander JE, Dufour L, Wyatt RD, Bush PB, Page RK. Acute toxicity of boric acid and boron tissue residues after chronic exposure in broiler chickens. Avi Dis. 1991;1:745-9. DOI: 10.2307/1591605

9. Białek M, Czauderna M, Krajewska KA, Przybylski W. Selected physiological effects of boron compounds for animals and humans: A review. J Anim Feed Sci. 2019;28(4):307-20. 10.22358/jafs/114546/2019

10. Whitworth MR, Pendleton GW, Hoffman DJ, Camardese MB. Effects of dietary boron and arsenic on the behavior of mallard ducklings. Environ Toxicol Chem. 1991;10(7):911-6. DOI: 10.1002/etc.5620100707

11. Ince S, Kucukkurt I, Cigerci IH, Fidan AF, Eryavuz A. The effects of dietary boric acid and borax supplementation on lipid peroxidation, antioxidant activity, and DNA damage in rats. J Trace Element Med Biol. 2010;24(3):161-4. DOI: 10.1016/j.jtemb.2010.01.003

12. Karimkhani H, Ozkoc M, Shojaolsadati P, Uzuner K, Donmez DB, Kanbak G. protective effect of boric acid and omega-3 on myocardial infarction in an experimental rat model. Biol Trace Element Res. 2020;9:1-9. DOI: 10.1007/s12011-020-02360-z

13. Dixon W. Effect analysis of experimental observation. Ann Rev Pharm Toxicol. 1980;20:441-426. DOI: 10.1146/annurev.pa.20.040180.002301

14. Moser VC. Application of neurobehavioral screening battery. J Am Toxicol. 1988;10:661-696. DOI: 10.3109/10915819109078658

15. Zamudio RS, Queredo CL, Garces L. The effect of acute stress and acute cortecosterone administration on the immobility response in rat. Brain Res. Bulletin. 2009;80:331-336. DOI: 10.1016/j.brainresbull.2009.09.005

16. Jones RB. The tonic immobility reaction of the domestic fowl: a review. World Poult Sci J. 1986;42(1):82-96. DOI :10.1079/WPS19860008

17. Buege JA, Aust SD. Microsomal lipid peroxidation. Methods Enzymol. 1978;52(1):302-310. DOI: 10.1016/S0076-6879(78)520326

18. Luna LG. Manual of histologic staining methods of the armed forces institute of pathology. $3^{\text {rd }}$ ed. New York: McGraw-Hill; 1986. DOI: 10.1016/s0031-3025(16)39410-7

19. van der Eijk JA, Rodenburg TB, de Vries H, Kjaer JB, Smidt H, Naguib M, Kemp B, Lammers A. Early-life microbiota transplantation affects behavioural responses, serotonin and immune characteristics in chicken lines divergently selected on feather pecking. Sci Rep. 2020;10(1):1-3. DOI: 10.1038/s41598-020-59125-w

20. Al-khafaf A, Ismail $\mathrm{H} \mathrm{Kh}$, Alsaidya A MA. Histopathological effects of experimental exposure to lead on nervous system in albino female rats. Iraqi J Vet Sci. 2021;35(1):45-48. DOI: 10.33899/ijvs.2019.126248.1273

21. Ince S, Kucukkurt I, Cigerci IH, Fidan AF, Eryavuz A. The effects of dietary boric acid and borax supplementation on lipid peroxidation, antioxidant activity, and DNA damage in rats. J Trace Elements Med Biol. 2010;24(3):161-4. DOI: 10.1016/j.jtemb.2010.01.003
22. Alabdaly Y Z, saeed M G, Al-hashemi H M. Effect of methotrexate and aspirin interaction and its relationship to oxidative stress in rats. Iraqi J Vet Sci. 2021;35(1):151-156. 10.33899/ijvs.2020.126490.133335

23. Hacioğlu C, Kar F, Senturk H, Kanbak G. Neuroprotective effects of boric acid against fluoride toxicity on rat synaptosomes. Med Sci Discovery. 2018;5(7):260-6. DOI: 10.17546/msd.443140

24. Moseley AE, Williams MT, Schaefer TL, Bohanan CS, Neumann JC, Behbehani MM, Vorhees CV, Lingrel JB. Deficiency in Na, KATPase $\alpha$ isoform genes alters spatial learning motor activity, and anxiety in mice. J Neurosci. 2007;27(3):616-26. DOI: 10.1523/JNEUROSCI.4464-06.2007

25. MacFabe DF, Rodríguez-Capote K, Hoffman JE, Franklin AE, Mohammad-Asef Y, Taylor AR, Boon F, Cain DP, Kavaliers M, Possmayer F, Ossenkopp KP. A novel rodent model of autism: intraventricular infusions of propionic acid increase locomotor activity and induce neuroinflammation and oxidative stress in discrete regions of adult rat brain. Am J Biochem Biotechnol. 2008;4(2):146-66. DOI: 10.3844/ajbbsp.2008.146.166

26. Dichiarante V, Milani R, Metrangolo P. Natural surfactants towards a more sustainable fluorine chemistry. Green Chem. 2018;20(1):13-27. DOI: $10.1039 / \mathrm{C} 7 \mathrm{GC} 03081 \mathrm{~A}$

27. Li Y, Sun Q, Su L, Yang L, Zhang J, Yang L, Liu B, Jiang C, Zhang Z. A single nanofluorophore "turn on" probe for highly sensitive visual determination of environmental fluoride ions. RSC advances. 2018;8(16):8688-93. DOI: $10.1039 / C 7 R A 13601 C$

28. Hassan E, El-sayed G, Hassan A, Abd S. Effect of pollution with lead, cupper, cadmium on gene expression pattern of liver GST and serum lysozymes in Nile tilapia (Oreochromis niloticus). Mansoura Vet Med J. 2020;21(3):53-60. DOI: 10.21608/mvmj.2020.310

29. Al-abdaly YZ, Al-Hamdany EK, Al-Kennany ER. Toxic effects of butylated hydroxytoluene in rats. Iraqi J Vet Sci. 2021;35(1):121-128. DOI: $10.33899 /$ ijvs.2020.126435.1322

30. Gazzano E, Bergandi L, Riganti C, Aldieri E, Doublier S, Costamagna C, Bosia A, Ghigo D. Fluoride effects: The two faces of janus. Curr Med Chem. 2010;17(22):2431-41. DOI: 10.2174/092986710791698503

31. Khaliq H, Juming Z, Ke-Mei P. The physiological role of boron on health. Biol Trace Element Res. 2018;186(1):31-51. DOI: 10.1007/s12011-018-1284-3

32. Abdullah RA, Taee FD, Thanoon IA. Effect of levofloxacin on some body tissues in mice. Iraqi $\mathrm{J}$ Vet Sci. 2021;35(1):109-111. DOI: 10.33899/ijvs.2020.126416.1316
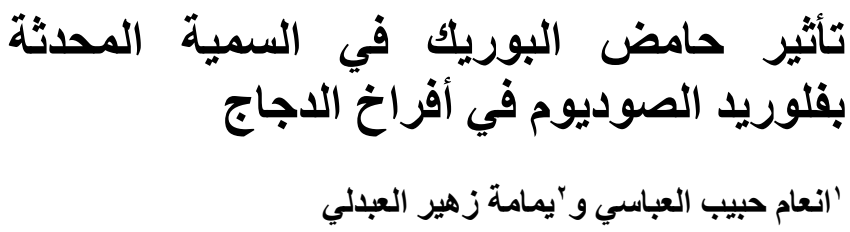

$$
\text { المديرية زر اعة نينوى، 'فرع الفيطري، جامعة الموصل، الموصل، والكيمياء الحياتية والأدوية، كلية }
$$

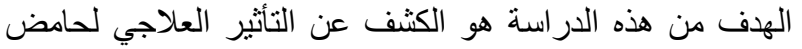

$$
\begin{aligned}
& \text { البوريك على مستوى السلوك العصبي (الفعالية الحركية) و التغييرات }
\end{aligned}
$$

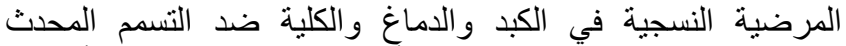

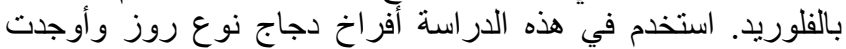

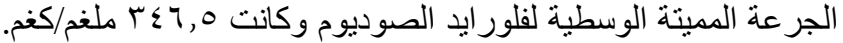

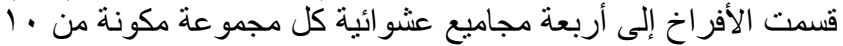

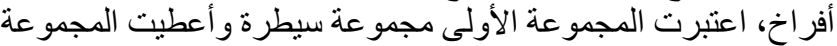


المرضية المتمثلة بوجود الالتهاب واحتقان الوريد البابي وتوسع وتئي

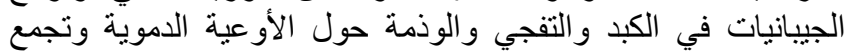

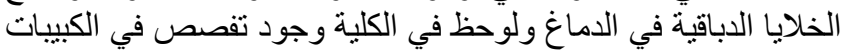

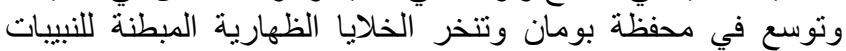

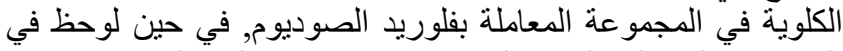

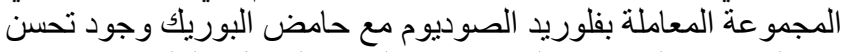

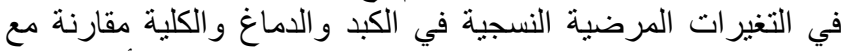

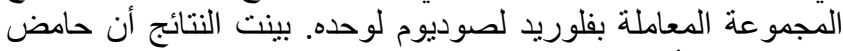

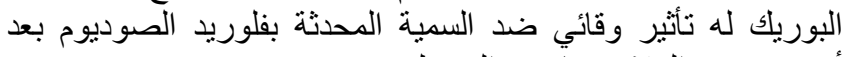
أسبو عين من العلاج بحامض البوريك

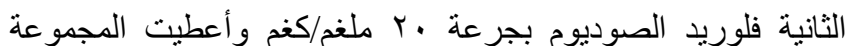

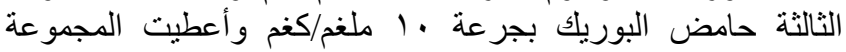

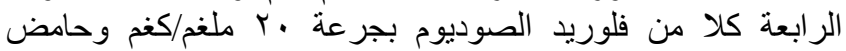

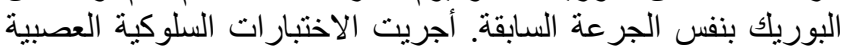

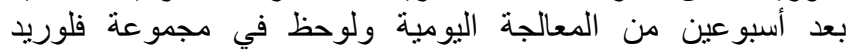

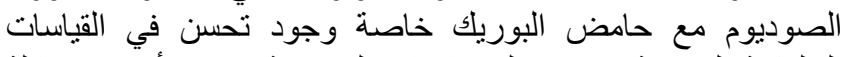
السلوكية العصبية وتحسن المضاعفات التي حدثت في الأنزيمات ناقلة ودئة

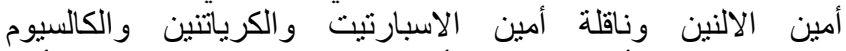

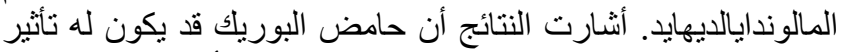

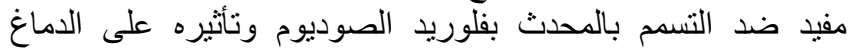
و الأعصاب و الكبد والكلية. تم دعم هذه النتائج بدراسة التغيرة التيرات التئ 